30 McPartlin JF, Dickson JAS, Swain VAJ. Meconium ileus. Immediate and ong-term survival. Arch Dis Child 1972;47:207-10

31 Wilmott RW, Tyson SL, Dinwiddie R, Matthew DJ. Survival rates in cystic fibrosis. Arch Dis Child 1983;58:835-6.

32 Shwachman H, Dooley RR, Guilmette F, Patterson PR, Weil C, Leubner H. Cystic fibrosis of the pancreas with varying degrees of pancreatic insufficiency. A $m$ f Dis Child 1956;92:347-68.

33 Karlish AJ, Tarnoky AL. Mucoviscidosis as a factor in chronic lung disease in adults. Lancet 1960;ii:514-5.

4 Anderson EG, Laszlo G, Brown HM. A case of mucoviscidosis in an adult. $B r f$ Dis Chest 1965;59:173-6.

35 Gracey M. Anderson CM. Cystic fibrosis of the pancreas in adolescence and adulthood. Australian Annals of Medicine 1969;18:91-101.
36 Tomashefski JF, Christoforidis AJ, Abdullah AK. Cystic fibrosis in young dults, Chest 1970:57:28-36.

37 Knoke JD, Stern RC, Doershuk CF, Boat TF, Matthews LW. Cystic fibrosis: the prognosis for five-year survival. Pediatr Res 1978;12:675-9.

38 Wilmott RW, Tyson SL, Matthew DJ. Cystic fibrosis survival rates. Am 7 Dis Child 1985;139:669-71.

39 Corey M, Levison H, Crozier D. Five- to seven-year course of pulmonary function in cystic fibrosis. Am Rev Kespir Dis 1976;114:1085-92.

40 Black D, Morris JN, Smith C, Townsend P. The Black report. In: Townsen $\mathrm{P}$, Davidson $\mathrm{N}$, eds. Inequalities in health. Harmondsworth: Penguin, 1982:39-233.

(Accepted 2 December 1988)

\title{
Plasma lipid and coagulation factor concentrations in insulin dependent diabetics with microalbuminuria
}

\author{
S L Jones, C F Close, M B Mattock, R J Jarrett, H Keen, G C Viberti
}

\section{Abstract}

Objective-To determine whether insulin dependent diabetics with microalbuminuria have significant abnormalities in concentrations of lipoproteins, apolipoproteins AI and B, fibrinogen, and clotting factor VII which could result in increased cardiovascular risk.

Design-Case-control study.

Setting-Outpatient department of a metabolic ward.

Patients-Group of 20 insulin dependent diabetics with urinary albumin excretion rates greater than $30 \mu \mathrm{g} / \mathrm{min}$ (microalbuminuria) and 20 individually matched insulin dependent diabetics with normal urinary albumin excretion rates (below $30 \mathrm{\mu g} / \mathrm{min}$ ) matched for age, sex, and duration of diabetes.

Interventions-Fasting venous blood samples were taken for determination of concentrations of glucose, glycated haemoglobin, lipoproteins, apolipoproteins AI and B, fibrinogen, and factor VII. Height, weight, arterial pressure, and usual insulin dose were recorded, and each patient was given a dietary questionnaire to be completed at home.

End point-Comparison of blood pressure and concentrations of lipoproteins, apolipoproteins AI and $B$, and fibrinogen in the diabetics with microalbuminuria and the controls.

Measurements and main results-Patients with microalbuminuria had significantly higher concentrations of low density lipoprotein cholesterol (mean $3.33(\mathrm{SE} 0.20) v 2.84(0.12) \mathrm{mmol} / \mathrm{l})$ and very low density lipoprotein cholesterol $(0.30(0.05) v 0.17$ $(0.03) \mathrm{mmol} / \mathrm{l})$ than controls but significantly lower concentrations of high density lipoprotein 2 subfraction cholesterol $(0.32 \quad(0.04) \quad v \quad 0.54$ $(0.04) \mathrm{mmol} / \mathrm{l})$. Concentrations of total triglyceride $(1.11(0.14) \quad v \quad 0.68(0.08) \quad \mathrm{mmol} / \mathrm{l})$, very low density lipoprotein triglyceride $(0.56(0.10) v 0.30$ $(0.05) \mathrm{mmol} / \mathrm{l})$, apolipoprotein B $(0.88(0.06) v 0.67$ $(0.03) \mathrm{g} / \mathrm{l})$ and fibrinogen $(2.2(0 \cdot 1) v 1.9(0 \cdot 1) \mathrm{g} / \mathrm{l})$, and diastolic arterial pressure (80 (2) $v 74$ (2) $\mathrm{mm} \mathrm{Hg}$ ), were also higher in patients with microalbuminuria.

Conclusions-Cardiovascular risk factorsnamely, disturbances in lipoprotein and apolipoprotein concentrations, increased fibrinogen concentration, and increased arterial pressure - are already present in insulin dependent diabetics with microalbuminuria. The increased risk of coronary heart disease in patients with clinical proteinuria may result from prolonged exposure to these risk factors, which are present before any impairment of renal function.

\section{Introduction}

Insulin dependent diabetics who develop clinical proteinuria have a much greater risk of premature death from cardiovascular complications than those without proteinuria. ${ }^{12}$ A subclinical increase in urinary excretion of albumin (microalbuminuria) predicts the development of persistent clinical proteinuria and renal failure in insulin dependent diabetics. ${ }^{3-6}$ In both prospective and cross sectional studies of non-insulin dependent diabetics microalbuminuria strongly indicated an increased risk of death from cardiovascular complications ${ }^{7-9}$ and it may also do so in nondiabetics. ${ }^{111}$

At the stage of clinical proteinuria and progressive renal failure changes in plasma lipoprotein concentrations, ${ }^{12-14}$ an increase in systemic blood pressure, ${ }^{12}$ and haemorrheological changes ${ }^{1516}$ have each been proposed as contributing to the increased cardiovascular risk. The situation is less clear in patients with microalbuminuria, in whom renal function is normal or even supranormal. Several workers have shown a raised arterial blood pressure at this stage,${ }^{4617}$ and control of blood glucose concentration has also been reported to be worse. ${ }^{17}$ Reports have suggested that profiles of lipoprotein concentrations are changed in diabetics with microalbuminuria and lie between those in diabetics with normal albuminuria and diabetics with clinical proteinuria. ${ }^{1314}$ The differences, however, were not significant and could have been accounted for by the poorer glycaemic control in the diabetics with microalbuminuria.

In this case-control study we compared concentrations of lipoproteins, apolipoproteins, fibrinogen, and factor VII in insulin dependent diabetics with microalbuminuria and diabetics with normal albumin excretion rates with similar control of their blood glucose concentration.

\section{Patients and methods}

Twenty insulin dependent diabetics with microalbuminuria were matched individually for age, sex, and duration of diabetes with 20 insulin dependent diabetics shown to have normal rates of albumin excretion. All were less than 65 years old and had had diabetes since before the age of 35 . All patients were Europids and received the standard dietary advice given to diabetics. None were taking drugs other than insulin apart from two patients with microalbuminuria, who were receiving long term thyroxine and cortisol replacement treatment. No patient had a history of renal disease or of drug or alcohol abuse.

As part of a collaborative screening programme ${ }^{18}$ we
Correspondence to:

$\operatorname{Br} \operatorname{Med} \mathcal{F}$ 1989;298:487-90 
identified insulin dependent diabetics with microalbuminuria - that is, those with urinary albumin concentrations exceeding $15 \mathrm{mg} / \mathrm{l}$ (or a ratio of albumin creatinine concentrations greater than 3.5 ) in their first morning urine sample and, in confirmatory tests over the next few weeks, overnight albumin excretion rates greater than $30 \mu \mathrm{g} / \mathrm{min}$ (geometric mean (range) 48 $(31-210) \mu \mathrm{g} / \mathrm{min})$. The control patients had urinary albumin concentrations $<15 \mathrm{mg} / \mathrm{l}$ (and ratios of albumin creatinine concentrations $<3.5$ ) and were excreting albumin at rates less than $30 \mu \mathrm{g} / \mathrm{min}$ based on analysis of at least two overnight collections of urine (geometric mean (range) $5(2-18) \mu \mathrm{g} / \mathrm{min})$. Patients with arterial blood pressure $\geqslant 160 / 95 \mathrm{~mm} \mathrm{Hg}$ or receiving treatment for hypertension were excluded from the screening programme. Table I gives the clinical features of the two groups.

The patients attended a metabolic ward at $830 \mathrm{am}$; all food, tea, coffee, alcohol, and tobacco had been prohibited from $10 \mathrm{pm}$ the previous night. The morning dose of insulin was withheld until after the observations were complete. After at least 10 minutes' rest in the supine position arterial pressure (phases I and $\mathrm{V}$ ) in the right arm was measured on two occasions three minutes apart to the nearest $2 \mathrm{~mm} \mathrm{Hg}$ by the same observer with a standard mercury sphygmomanometer. The mean of the two measurements was used for analysis. A blood sample was taken without cuffing, a history of smoking was recorded, and a dietary questionnaire was completed at home for assessment of the intake of important macronutrients. Dietary data were analysed by the computerised program adapted for the Medical Research Council Caerphilly and Speedwell collaborative heart disease studies. ${ }^{19} 20$

The glomerular filtration rate was measured by monitoring the clearance of edetic acid labelled with chromium-51 (given in a single bolus injection) ${ }^{21}$ either on the same day as the other measurements were taken or on a different occasion, but always within six months of the study visit, in all patients with microalbuminuria and in 14 of the controls.

\section{MEASUREMENTS}

The following measurements were made: plasma glucose concentration by the glucose oxidase method with a Yellow Springs analyser; haemoglobin $A_{1}$ concentration by Corning gel electrophoresis (normal range $5 \cdot 0-7 \cdot 6 \%$ ); plasma concentration of electrolytes,

TABLE I-Clinical features of 20 insulin dependent diabetics with microalbuminuria and 20 matched controls

\begin{tabular}{lcc}
\hline & $\begin{array}{c}\text { Patients with } \\
\text { microalbuminuria }\end{array}$ & Controls \\
\hline No male & 17 & 17 \\
Mean (range) age (years) & $39(19-59)$ & $39(21-60)$ \\
Mean (range) duration of diabetes (years) & $20(8-32)$ & $20(9-35)$ \\
Mean (range) dose of insulin $(\mathrm{U} / \mathrm{kg} / \mathrm{day})$ & $0 \cdot 7(0 \cdot 4-1 \cdot 2)$ & $0 \cdot 7(0 \cdot 5-1 \cdot 5)$ \\
Mean (range) body mass index $\left(\mathrm{kg} / \mathrm{m}^{2}\right)$ & $25(19-32)$ & $24(20-29)$ \\
\hline
\end{tabular}

TABLE II-Geometric mean (SE) concentrations (mmol/l) in 20 insulin dependent diabetics with microalbuminuria and 20 matched controls

\begin{tabular}{|c|c|c|c|c|}
\hline Lipoprotein & $\begin{array}{c}\text { Patients with } \\
\text { microalbuminuria }\end{array}$ & Controls & $\begin{array}{l}\text { Mean difference } \\
\text { 95\% confidence intervals) }\end{array}$ & $\mathrm{p}$ Value \\
\hline \multicolumn{5}{|l|}{ Cholesterol: } \\
\hline Total & $5.41(0.25)$ & $4.98(0 \cdot 18)$ & $0 \cdot 26(-0.30$ to 0.94$)$ & \\
\hline Low density lipoprotein & $3 \cdot 33(0 \cdot 20)$ & $2 \cdot 84(0 \cdot 12)$ & $0.44(0.04$ to 0.89$)$ & $<0.02$ \\
\hline Very low density lipoprotein & $0.30(0.05)$ & $0.17(0.03)$ & $0 \cdot 17(0 \cdot 02$ to $0 \cdot 33)$ & $<0.025$ \\
\hline High density lipoprotein & $1.07(0.06)$ & $1.24(0.06)$ & $-0.18(-0.35$ to 0.01$)$ & \\
\hline High density lipoprotein 2 & $0.32(0.04)$ & $0.54(0.04)$ & $-0.22(-0.33$ to -0.09$)$ & $<0.002$ \\
\hline High density lipoprotein 3 & $0.76(0.04)$ & $0.75(0.04)$ & $-0.01(-0.14$ to 0.12$)$ & \\
\hline \multicolumn{5}{|l|}{ Triglyceride: } \\
\hline Total & $1 \cdot 11(0 \cdot 14)$ & $0.68(0.08)$ & $0.49(0.21$ to 0.81$)$ & $<0.001$ \\
\hline Low density lipoprotein & $0.35(0.04)$ & $0 \cdot 28(0.01)$ & $0 \cdot 12(-0.05$ to $0 \cdot 30)$ & \\
\hline Very low density lipoprotein & $0.56(0 \cdot 10)$ & $0.30(0.05)$ & $0.36(0.09$ to 0.67$)$ & $<0.005$ \\
\hline High density lipoprotein & $0.19(0.02)$ & $0 \cdot 18(0.02)$ & $0.02(-0.05$ to 0.08$)$ & \\
\hline
\end{tabular}
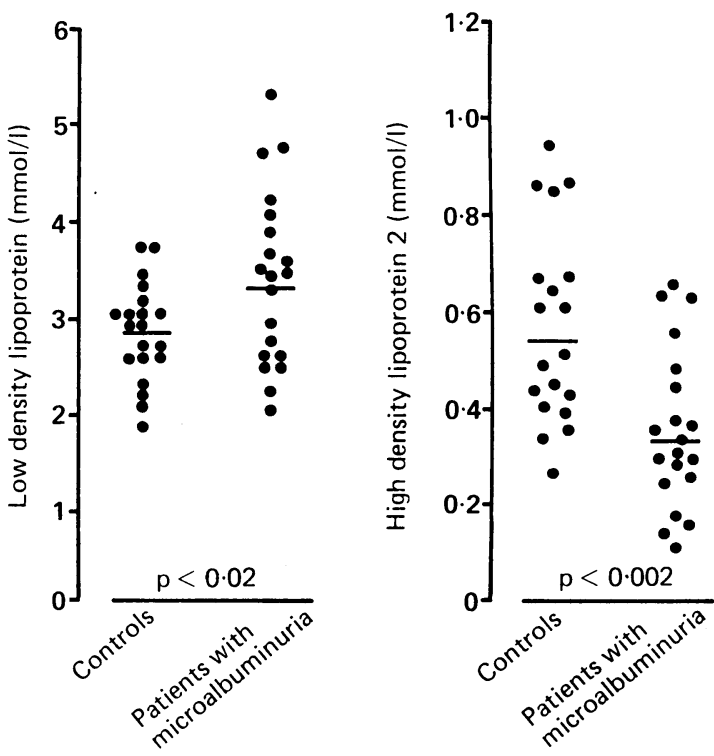

Concentrations of low density lipoprotein cholesterol and high density lipoprotein 2 cholesterol in 20 insulin dependent diabetics with microalbuminuria and 20 matched controls. Horizontal bars indicate geometric means

urea, and creatinine with a multichannel autoanalyser (Hitachi, Boehringer Corporation, United Kingdom); and urinary albumin concentration by radioimmunoassay. ${ }^{3}$

Blood for determination of lipoprotein concentrations was collected in plain glass tubes and left for the serum to separate (less than two hours). The serum was stored at $4^{\circ} \mathrm{C}$ until further analysis, which was always performed within five days. Low density, very low density, and high density lipoproteins were separated by ultracentrifugation ${ }^{22}$ and high density lipoprotein subfractions by a combination of precipitation ${ }^{23}$ and ultracentrifugation. Serum concentrations of cholesterol, triglycerides, and lipoprotein subfractions were assayed by enzymatic colorimetric techniques (cholesterol oxidase/peroxidase-amidopyrine and glycerol phosphate oxidase/peroxidase-amidopyrine, Boehringer Mannheim, Germany), with a Cobas-Bio centrifugal analyser (Roche, United Kingdom). Concentrations of apolipoproteins AI and B were measured by immunoturbidimetry with a Cobas-Bio analyser and Orion Diagnostica antiserum and reagents (Oxoid, United Kingdom). A separate, citrated blood sample was taken for measurement of plasma fibrinogen and clotting factor VII concentrations (Coag-A-Mate/2 analyser, General Diagnostic Products, United States).

\section{STATISTICS}

The significance of differences was assessed by paired $t$ test unless otherwise stated. Data are expressed as means (SEM) and means of the differences with $95 \%$ confidence intervals. Log transformation was applied to data on lipids because of their positively skewed distributions.

\section{Results}

Concentrations of low density and very low density lipoprotein cholesterol and total triglycerides and very low density triglycerides were significantly higher in the diabetics with microalbuminuria compared with the controls (table II). The concentration of high density lipoprotein 2 cholesterol was reduced in those with microalbuminuria, but there were no significant differences in the concentrations of total or high density lipoprotein 3 cholesterol. The figure shows the concentrations of low density lipoprotein cholesterol and high density lipoprotein 2 cholesterol in each 
TABLE III-Mean (SE) concentrations of apolipoproteins AI and B in 20 insulin dependent diabetics with microalbuminuria and 20 matched controls

\begin{tabular}{|c|c|c|c|}
\hline . & $\begin{array}{c}\text { Patients with } \\
\text { microalbuminuria }\end{array}$ & Controls & $\begin{array}{c}\text { Mean difference } \\
\text { (95\% confidence } \\
\text { interval) }\end{array}$ \\
\hline Apolipoprotein AI (g/l) & $1 \cdot 14(0.05)$ & $1 \cdot 16(0 \cdot 03)$ & $-0.02(-0.15$ to 0.12$)$ \\
\hline Apolipoprotein B (g/l) & $0.88(0.06)$ & $0.67(0.03)$ & $0 \cdot 21^{\star}(0 \cdot 11$ to $0 \cdot 32)$ \\
\hline Apolipoprotein AI:apolipoprotein B & $1 \cdot 36(0.08)$ & $1.80(0.08)$ & $-0.44^{\star}(-0.65$ to -0.22$)$ \\
\hline
\end{tabular}

TABLE IV-Mean (SE) fasting plasma glucose, haemoglobin Al, plasma creatinine, and albumin concentrations in 20 insulin dependent diabetics with microalbuminuria and 20 matched controls

\begin{tabular}{lcc}
\hline & $\begin{array}{c}\text { Patients with } \\
\text { microalbuminuria }\end{array}$ & Controls \\
\hline Fasting plasma glucose $(\mathrm{mmol} / \mathrm{l})$ & $13 \cdot 9(1 \cdot 5)$ & $13 \cdot 0(1 \cdot 6)$ \\
Haemoglobin A1 $(\%)$ & $8 \cdot 6(0 \cdot 4)$ & $8 \cdot 3(0 \cdot 3)$ \\
Plasma creatinine $(\mu \mathrm{mol} / \mathrm{l})$ & $98(4)$ & $92(2)$ \\
Plasma albumin $(\mathrm{mmol} / \mathrm{l})$ & $47(1)$ & $45(1)$ \\
\hline
\end{tabular}

TABLE $\mathrm{V}-$ Mean $(S E)$ dietary intake (g/day) of important macronutrients in 20 microalbuminuric insulin dependent diabetics with microalbuminuria and 20 matched controls

\begin{tabular}{lcc}
\hline Macronutrient & $\begin{array}{c}\text { Patients with } \\
\text { microalbuminuria }\end{array}$ & Controls \\
\hline Total fat & $73(6)$ & $78(5)$ \\
Saturated fat & $32(3)$ & $34(2)$ \\
Polyunsaturated fat & $11(1)$ & $13(2)$ \\
Protein & $73(4)$ & $77(4)$ \\
Carbohydrate & $205(15)$ & $209(12)$ \\
\hline
\end{tabular}

patient. Apolipoprotein B concentration was increased in the patients with microalbuminuria, and the ratio of apolipoprotein AI to apolipoprotein B concentration was reduced (table III).

The fibrinogen concentration was significantly higher in those with microalbuminuria $(2 \cdot 2(0 \cdot 1) \mathrm{g} / \mathrm{l})$ than in the controls $(1.9(0.1) \mathrm{g} / \mathrm{l}$; mean difference $(95 \%$ confidence interval) $0.3(0.0$ to 0.6$) ; \mathrm{p}<0.05)$, but this was not so for factor VII concentration $(0.9(0 \cdot 1) v$ $1 \cdot 1(0 \cdot 1) \mathrm{g} / \mathrm{l})$. The diabetics with microalbuminuria had higher arterial diastolic pressure $(80$ (2) $v$ 74 (2) $\mathrm{mm} \mathrm{Hg} ; \mathrm{p}=0.04$ ); systolic pressure was also higher, but the difference was not significant $(132(4) v$ 127 (2) $\mathrm{mm} \mathrm{Hg}$ ). Fasting plasma glucose, glycated haemoglobin, and serum albumin and creatinine concentrations were similar in the two groups (table IV), as were body mass index and daily dose of insulin (table I). The mean glomerular filtration rate in the 20 patients with microalbuminuria was 113 (6) $\mathrm{ml} / \mathrm{min} / 1 \cdot 73 \mathrm{~m}^{2}$, which was not significantly different from that of the 14 controls in whom it was measured (mean 111 (3) $\mathrm{ml} / \mathrm{min} / 1.73 \mathrm{~m}^{2} ; \mathrm{p}=0.77$ by unpaired $t$ test). Dietary intake of total, saturated, and polyunsaturated fats and protein and carbohydrate did not differ significantly between the two groups (table $\mathrm{V})$.

\section{Discussion}

Our results show that insulin dependent diabetics with microalbuminuria, a group at risk of clinical nephropathy, have significant alterations in serum lipoprotein and apolipoprotein and plasma fibrinogen concentrations. Several factors could be responsible for the differences in concentrations of lipoprotein subfractions. The extent of glycaemic control influences lipoprotein concentrations in young insulin dependent diabetics, ${ }^{24-26}$ and differences in lipid concentrations have been described in diabetics with microalbuminuria with poor glycaemic control compared with concentrations seen in diabetics with normal albumin concentrations with good glycaemic control. ${ }^{13}$ The extent of glycaemic control was, however, similar in the two groups in our study, as were the intake of important macronutrients, the body mass index, and the insulin dose. Renal function, as measured by serum creatinine concentration and glomerular filtration rate, was comparable between diabetics with microalbuminuria and controls. An increased loss of albumin, however, could contribute to differences in lipoprotein concentrations. Severe proteinuria is associated with disturbances of serum lipid concentrations, and together with loss of albumin, the loss of apolipoproteins and small lipoproteins in urine may lead to increased synthesis of albumin and apolipoproteins with altered ratios of high to low density lipoprotein concentrations. ${ }^{27.29}$ Whether this applies to the patients with microalbuminuria with their considerably smaller loss of albumin is not known.

In addition to absolute concentrations, the relative concentrations of lipoproteins and apolipoproteins are also important in atherogenesis. ${ }^{3031}$ Ratios of high density lipoprotein cholesterol to low density lipoprotein cholesterol concentrations and apolipoprotein AI to apolipoprotein B concentrations were significantly lower in the patients with microalbuminuria, a finding consistent with their higher risk of coronary heart disease.

Both in the general and in the diabetic population plasma fibrinogen concentrations have been associated with an increased prevalence of vascular complications, ${ }^{153233}$ although whether this is causal, concomitant, or simply a consequence of the vascular disease has not been determined. The processes in the glomerular and arterial walls responsible for the increased permeability to albumin in the patients with microalbuminuria could conceivably lead to a rise in plasma fibrinogen concentration, ${ }^{34}{ }^{35}$ even though whether this increase results from a relative overproduction of fibrinogen or a reduction in its degradation is not known. ${ }^{36}$ In both insulin dependent diabetics and experimental diabetic animals microalbuminuria is associated with an increase in whole body escape of albumin through the capillaries ${ }^{31}$ and intravascular permeation of protein. ${ }^{32}$ Larger vessel walls may also be more readily penetrated by other substances, including lipoproteins, where binding by specific apolipoprotein receptors on macrophages, smooth muscle cells, and fibrinoblasts could result in acceleration of the atherosclerotic process. ${ }^{37} 38$

In addition to the postulated increased risk of atherosclerosis altered lipoprotein concentrations, increased fibrinogen concentration, and arterial blood pressure could also contribute to progression of the renal changes. Moorhead et al suggested that increased circulating low density lipoproteins, by binding to the polyanionic glycoproteins on the glomerular basement membrane, could increase the permeability of the membrane, leading to accumulation of lipoproteins and other substances within the mesangium, and stimulate mesangial cell proliferation. ${ }^{39}$ In animal models of renal disease high fat diets lead to abnormal plasma lipid concentrations and accelerate renal damage. ${ }^{40+1}$

In conclusion, this study has shown that at least some of the prerequisites for the development of atherosclerosis, such as abnormalities in lipoprotein concentrations, hyperfibrinogenaemia, and raised arterial pressure, are found in insulin dependent diabetics with microalbuminuria, itself a strong predictor of later development of clinical proteinuria and greatly increased risk of coronary heart disease. The preconditions for atherosclerosis thus exist well before the onset of renal failure.

We thank Ms A Mabbott, Mr G Scott, and Ms A Collins for technical help; Mrs R Dodds for nutritional analysis; and the department of radiological sciences for estimating glomerular filtration rates. The study was supported in part by grants 
from the Department of Health, the special trustees of Guy's Hospital, and Bayer, UK Limited.

1 Borch-Johnsen K, Andersen PK, Deckert T. The effect of proteinuria on relative mortality in type 1 (insulin-dependent) diabetes mellitus. Diabetologia 1985;28:590-6.

2 Krolewski AS, Kosinski EJ, Warram JH, et al. Magnitude and determinants of coronary artery disease in juvenile-onset, insulin-dependent diabetes mellitus. Am f Cardiol 1987;59:750-5.

3 Viberti GC, Hill RD, Jarrett RJ, Argyropoulos A, Mahmud U, Keen H. Microalbuminuria as a predictor of clinical nephropathy in insulindependent diabetes mellitus. Lancet 1982;i:1430-2.

4 Mathiesen ER, Oxenbell B, Johansen K, Svendsen PA, Deckert T. Incipient nephropathy in type 1 (insulin-dependent) diabetes. Diabetologia 1984;26: 406-10.

5 Parving HH, Oxenboll B, Svendsen PA, Sandahl-Christiansen J, Andersen AR. Early detection of patients at risk of developing clinical nephropathy. A longitudinal study of urinary albumin excretion. Acta Endocrinol 1982;100: 550-5

6 Mogensen CE, Christensen CK. Predicting diabetic nephropathy in insulin dependent patients. $N$ Engl f Med 1984;311:89-93.

Mogensen CE. Microalbuminuria predicts clinical proteinuria and early mortality in maturity onset diabetes. $N$ Engl $\mathcal{F}$ Med 1984;6:356-60.

8 Jarrett RJ, Viberti GC, Argyropoulos A, Hill RD, Mahmud U, Murrells TJ. Microalbuminuria predicts mortality in non-insulin dependent diabetes. Diabetic Med 1984;1:17-9.

9 Mattock MB, Keen H, Viberti GC, et al. Coronary heart disease and urinary albumin excretion rate in type II (non-insulin-dependent) diabetic patients. Diabetologia 1988;31:82-7.

10 Yudkin JS, Forrest RD, Jackson CA. Microalbuminuria as predictor of vascular disease in non-diabetic subjects. Islington diabetes survey. Lance 1988;ii:530-3.

11 Cruickshank JK, Andersen NM, Haines AP. "Spot" urinary albumin creatinine: a positive independent relation to systolic blood pressure in the general population: an index of vascular risk. Clin Sci 1987;72(suppl 16):43.

12 Winocour PH, Durrington PN, Ishola M, Anderson DC, Cohen H. Influence of proteinuria on vascular disease, blood pressure, and lipoproteins in insulin dependent diabetes mellitus. Br Med $\mathcal{F}$ 1987;294:1648-51.

13 Jensen T, Stender S, Deckert T. Abnormalities in plasma concentrations of lipoproteins and fibrinogen in type I (insulin-dependent) diabetic patients with increased urinary albumin excretion. Diabetologia 1988;31:142-5.

14 Vannini P, Ciavarella A, Flammini M, et al. Lipid abnormalities in insulindependent diabetic patients with albuminuria. Diabetes Care 1984:7:151-4.

15 Fuller JH, Keen $\mathrm{H}$, Jarrett RJ, et al. Haemostatic variables associated with diabetes and its complications. Br Med f 1979;ii:964-6.

16 Kwaan HC, Colwell JA, Cruz S, Suwanwela N, Dobbie JG. Increased platelet aggregation in diabetes mellitus. $\mathcal{F}$ Lab Clin Med 1972;80:236-46.

17 Wiseman MJ, Viberti GC, Mackintosh D, Jarrett RJ, Keen H. Glycaemia, arterial pressure and micro-albuminuria in type 1 (insulin-dependent) diabetes mellitus. Diabetologia 1984;26:401-5.

18 Microalbuminuria Collaborative Study Group, England. Sex, diabetes duration and microalbuminuria in IDDM. Diabetes and Metabolism 1988;14 $183-4$

19 Caerphilly and Speedwell Collaborative Group. Caerphilly and Speedwell collaborative heart disease studies. F Epidemiol Community Health 1984;38 259-62.

20 Yarnell JWG, Fehily AM, Millbank JE, Sweetnam PH, Walker CL. A shor dietary questionnaire for use in an epidemiological survey: comparison with weighed dietary records. Hum Nutr Appl Nutr 1983;37A:103-12.

21 Veall N, Gibbs GP. The accurate determination of tracer clearance rates and equilibrium distribution volumes from single injection plasma measurements using numerical analysis. In: Joekes AM, ed Radionuclides in nephrology. London: Academic Press, 1982:125-30.

22 Carlson K. Lipoprotein fractionation. F Clin Pathol 1973;26(suppl 5):32-7.

3 Warnick GR, Benderson J, Albers JJ. Dextran sulphate-Mg2 + precipitation procedure for quantitation of high-density lipoprotein cholesterol. Clin Chem 1982;28:1379-88.

24 Pietri A, Dunn FL, Raskin P. The effect of improved diabetic control on plasma lipid and lipoprotein levels. A comparison of conventional therapy and continuous subcutaneous insulin infusion. Diabetes 1980;29:1001-5.

25 Tamborlane WV, Sherwin RS, Genel M, Felig P. Restoration of normal lipid and aminoacid metabolism in diabetic patients treated with a portable insulin-infusion pump. Lancet 1979;i:1258-61.

26 Lopes-Virella MF, Wohltmann HJ, Loadholt CB, Buse MG. Plasma lipids and lipoproteins in young insulin-dependent diabetic patients: relationship with control. Diabetologia 1981;21:216-23.

27 Felts JM, Mayerle JA. Urinary loss of plasma high density lipoprotein-a possible cause of hyperlipidaemia of the nephrotic syndrome. Circulation 1974;50(suppl 3):263.

28 Short CD, Durrington PN, Mallick NP, Hunt LP, Tetlow L, Ishola M. Serum and urinary high density lipoproteins in glomerular disease with proteinuria. Kidney Int 1986;29:1224-8.

29 Shore VG, Forte T, Licht H, Lewis SB. Serum and urinary lipoproteins in the human nephrotic syndrome: evidence for renal catabolism of lipoproteins. Metabolism 1982;31:258-68.

30 Gordon T, Castelli WP, Hjortland MC, Kannel WB, Dawber TR. High density lipoprotein as a protective factor against coronary heart disease. The Framingham study. Am f Med 1977;62:707-14.

31 Durrington PN, Ishola M, Hunt L, Arrol S, Bhatnagar D. Apolipoproteins (a), AI and B and parenteral history in men with early onset ischaemic heart disease. Lancet 1988 ; i: 1070-3.

32 Meade TW, Mellows S, Brozovic M, et al. Haemostatic function and ischaemic heart disease. Principal results of the Northwick Park heart study. Lancet 1986;ii:533-7.

33 Stone MC, Thorpe JM. Plasma fibrinogen-a major coronary risk factor. $f R$ Coll Gen Pract 1985;35:565-9.

34 Feldt-Rasmussen B. Increased transcapillary escape rate of albumin in type 1 (insulin-dependent) diabetic patients with microalbuminuria. Diabetologic 1986;29:282-6

35 Williamson JR, Chang K, Tilton RG, et al. Increased vascular permeability in spontaneously diabetic $\mathrm{BB} / \mathrm{W}$ rats and in rats with mild versus severe streptozotocin-induced diabetes. Diabetes 1987;36:813-21.

36 Bent-Hanson L, Deckert T. Metabolism of albumin and fibrinogen in type (insulin-dependent) diabetes mellitus. Diabetes Res 1988;7:159-64.

37 Lyons TJ, Klein RL, Baynes JW, Stevenson HC, Lopes-Virella MF. Stimulation of cholesteryl ester synthesis in human monocyte-derived macrophages by low-density lipoproteins from type 1 (insulin-dependent) diabetic patients: the influence of non-enzymatic glycosylation of lowdiabetic patients: the influence of non-enzymatic
density lipoproteins. Diabetologia 1987;30:916-23.

38 Lopez-Virella MF, Sherer GK, Lees AM, et al. Surface binding, internalisation and degradation by cultured human fibroblasts of low density lipoproteins isolated from type 1 (insulin-dependent) diabetic patients: changes with metabolic control. Diabetologia 1982;22:430-6.

39 Moorhead JF, Chan MK, El-Nahas M, Varghese Z. Lipid nephrotoxicity in chronic progressive glomerular and tubulo-interstitial disease. Lancet 1982 ii: $1309-1$

40 French SW, Yamanaka W, Ostwald R. Dietary induced glomerulosclerosis in the guinea pig. Arch Pathol 1967;83:204-10.

41 Al-Shebeb T, Frohlich J, Magil AB. Giomerular disease in hypercholestero guinea pigs: a pathogenetic study. Kidney Int 1988;33:498-507.

(Accepted 9 December 1988$)$

\title{
Transplants from living donors in the United Kingdom and Ireland: a centre survey
}

\author{
P K Donnelly, D G Clayton, A R Simpson
}

\begin{abstract}
Departments of Surgery and Community Health, University of Leicester P K Donnelly, FRCS, senior lecturer in surgery D G Clayton, PHD, senior lecturer in medical statistics

Transplant Unit, Leicester General Hospital,

Leicester LE5 4PW

A R Simpson, SRN, transplant coordinator
\end{abstract}

Correspondence to: $\mathrm{Mr} \mathrm{P} \mathrm{K}$ Donnelly, Department of Surgery, Leicester General Hospital, Leicester

LE5 4PW.

\section{Abstract}

A survey was carried out to determine for the first time the extent of transplantation from living donors in the United Kingdom and Republic of Ireland and the views of transplant surgeons regarding future developments. Questionnaires were sent to 32 transplant centres representing 18 health regions and covered their extent of experience of transplantation, sources of donors, ages of donors and recipients, outcome of transplantation, and views on expansion of living donor transplantation services. Replies received from 27 transplant centres representing 17 health regions gave data on more than 1200 transplants from living donors. Transplants from living donors accounted for $0-25 \%$ of the total experience of health regions. Two centres had abandoned living donor transplantation. Sixty per cent of transplant surgeons favoured expansion of the living donor programme to meet a shortage of kidneys from cadavers, and the remainder thought that existing programmes were optimal.

Living donor transplantation promises to be an important factor in the future planning of health care resources.

\section{Introduction}

When reviewing kidney transplantation in Leicester during 1987 we found a reduction in the number of transplants (table) consequent on a diminishing supply of donor organs despite vigorous campaigns to encourage organ donation. No transplantations from living donors had been performed in the area since 1984 even though seven of the eight previous recipients had functioning grafts. Possible reasons for the decline in transplantations from living donors were the excellent survival of patients with grafts from cadavers after treatment with cyclosporin, uncertainty over the long 